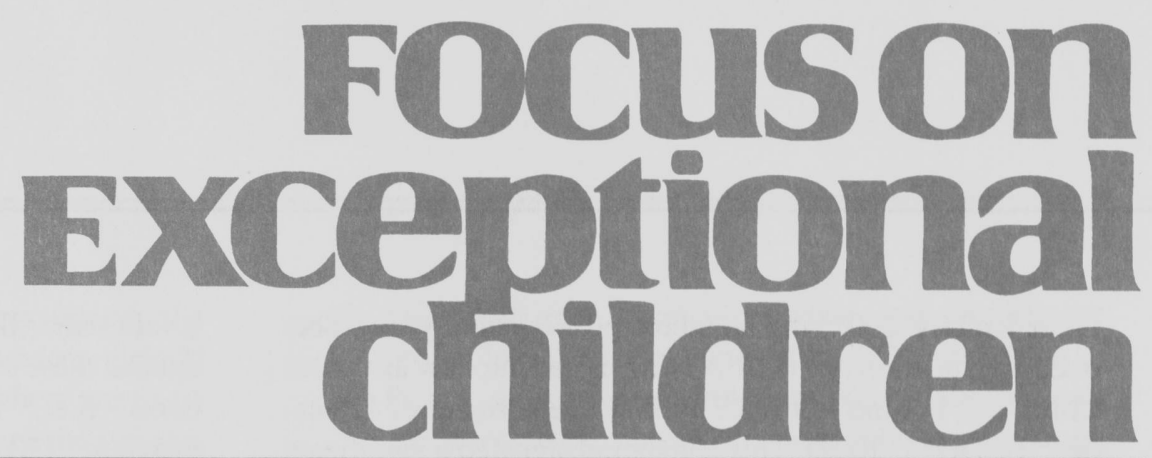

\title{
School Principals and Special Education: Creating the Context for Academic Success
}

\author{
Michael DiPaola, Megan Tschannen-Moran, and Chriss Walther-Thomas
}

For almost 30 years, school leaders have been challenged to meet both the intent and the spirit of federal laws regarding the education of students with disabilities (DiPaola \& Walther-Thomas, 2003). Special education has evolved from segregated classrooms characterized by low academic expectations, social isolation, and poor curriculum (Turnbull \& Cilley, 1999) to widespread recognition that effective special education is not a "place" in a school building. Instead, special education is an integrated system of academic and social supports designed, implemented, and monitored to ensure that students with disabilities are appropriately educated (National Association of Elementary School Principals [NAESP] \& ILIAD Project, 2001; National Commission on Teaching and America's Future [NCTAF], 1996; National Council on Disability [NCD], 1995; National Research Council [NRC], 1997; National Staff Development Council [NSDC], 2001).

Over the same time period, the United States has embraced a sweeping series of school reforms designed to make public schools more rigorous learning environments. These efforts accelerated dramatically over the past decade as virtually all states adopted comprehensive academic standards. In addition, many states implemented corresponding accountability systems to ensure that students, teachers, and administrators would all achieve performance accountability (Thurlow, 2000; Vernon, Baytops, McMahon, Holland, \& Walther-Thomas, 2002). In many communities, critical school milestones such as grade promotion and high school graduation, as well as professional tenure and school accreditation, are being determined by "high-stakes" test results (Giacobbe, Livers, Thayer-Smith, \& Walther-Thomas, 2001).

Dr. DiPaola, an associate professor, and Dr. Megan Tschannen-Moran, an assistant professor, both teach in the school of education at the College of William \& Mary. Chriss Walther-Thomas is professor and chair of the special education department in the school of education at the University of Kansas. 
In January 2002, the reauthorized Elementary and Secondary Education Act (ESEA) was signed into law as the No Child Left Behind Act (NCLB; U.S. Department of Education [USDOE], 2002). This legislation signaled a significant change in the federal government's role in $\mathrm{K}-12$ education. Built on the foundation of state-level efforts, NCLB aims to take public education to higher levels of academic reform. It sets high expectations for all students-including those traditionally left behind in the past_-and requires rigorous and highly regulated education programs. NCLB has raised the academic bar for students with disabilities. Even though the Individuals with Disabilities Education Act (IDEA; USDOE, 1997) mandates "access" to general education curriculum for students with disabilities, access will not be enough for students with disabilities and others at risk to achieve NCLB goals. Concerted school action will be required.

Under NCLB, student achievement must be measured by tests closely aligned with comprehensive state academic standards. Scores must be reported in terms of proficiency

\section{Focuson
exceptional
childien}

ISSN 0015-511X FOCUS ON EXCEPTIONAL CHILDREN (USPS 203-360) is published monthly except June, July, and August as a service to teachers, special educators, curriculum specialists, administrators, and those concerned with the special education of exceptional children. This publication is annotated and indexed by the ERIC Clearinghouse on Handicapped and Gifted Children for publication in the monthly Current Index to Journals in Education (CIJE) and the quarterly index, Exceptional Children Education Resources (ECER). The full text of Focus on Exceptional Children is also available in the electronic versions of the Education Index. It is also available in microfilm from Xerox University Microfilms, Ann Arbor, MI. Subscription rates: individual, \$36 per year; institutions, \$48 per year. Copyright (C) 2004, Love Publishing Company. All rights reserved. Reproduction in whole or part without written permission is prohibited. Printed in the United States of America. Periodical postage is paid at Denver, Colorado. POSTMASTER: Send address changes to:

Love Publishing Company

Executive and Editorial Office

P.O. Box 22353

Denver, Colorado 80222

Telephone (303) 221-7333

\section{EDITORIAL BOARD}

Edwin Ellis

University of Alabama
Tim Lewis

University of Missouri

Chriss-Walther Thomas

University of Kansas

Susan T. Warhover Editor
Stanley F. Love

Publisher levels rather than percentile scores to enable measurement against these standards. NCLB expects all public school students (i.e., 100\%) to demonstrate "adequate yearly progress" (AYP) on state assessments by 2014 (USDOE, 2002). To access student progress regularly, and to keep public pressure on state and local education agencies, NCLB requires that $95 \%$ of all students participate in the standard state-level assessment program. No longer can teachers, administrators, and parents arbitrarily choose to exclude low-achieving students from the process. Assessment scores must be disaggregated so principals, teachers, and others can study the performance of high-risk students in four targeted sub-groups:

1. Children with disabilities

2. Children with limited English proficiency

3. Children of racial minority status

4. Children at economic disadvantage

Not surprisingly, annual assessment scores are receiving widespread state and national attention. Results are reported in newspapers school by school, district by district, and state by state. The competition is keen and the tensions are high. From coast to coast, public officials (e.g., governors, superintendents, principals) are in the headlines and, in many ways, in the academic headlights, as they try to explain low test scores to their constituents. Unfortunately, few of them effectively describe the complex challenges that schools face in implementing NCLB (e.g., insufficient resources, high teacher turnover, teacher shortages, unrealistic "highly qualified" requirements, and standardized test limitations).

Despite NCLB and IDEA provisions, bad press, and earnest aspirations, daily educators find themselves performing academic triage-reluctantly neglecting some in favor of others who show better signs of academic survival in today's rigorous and fast-paced learning environments (Thurlow, 2000; Vernon et al., 2002). In addition to the pressures facing general educators, one of the greatest challenges in public schools today is to find enough qualified special education teachers (National Center for Education Statistics [NCES], 2003; USDOE, 2002). As many as half of all new special educators leave the field within the first 3 years because of poor administrative support, limited preparation, complex job responsibilities, and overwhelming paperwork requirements (Billingsley \& Cross, 1991; Boe, Barkanic, \& Leow, 1999; Miller, Brownell, \& Smith, 1999).

Given the teacher shortages and rapid teacher turnover, many urban and rural districts are forced to hire special educators on "emergency" certificates. Frequently, these neophytes end up in some of the most challenging classrooms within school districts, with little or no preparation in special education. Not surprisingly, most don't stay long. 
As school pressures and teacher shortages mount, the value of capable school leadership cannot be underestimated (Billingsley, 2004). If students and their teachers are to be successful in today's schools, principals must be their champions. As the instructional leaders in their building, principals are responsible for developing a school culture that embraces high academic standards and expectations for all students (Boyer \& Lee, 2001). Good leaders foster working relationships based on trust, shared responsibility, collaboration, and teamwork (NSDC, 2001; Tschannen-Moran, 2004; Walther-Thomas, Korinek, McLaughlin, \& Williams, 2000; K. S. Whitaker, 1998). They are personally invested in providing their students with comprehensive, high-quality instructional programs that are firmly grounded in educational research (Barth et al, 1999; Billingsley, Carlson, \& Klein, 2004; Crockett, 2002; NAESP, 2001a, 200lb).

\section{THE PRINCIPAL'S ROLE IN PROVIDING EFFECTIVE SPECIAL EDUCATION SERVICES}

Administrative leadership is a powerful predictor of positive teacher attitudes in schools as they implement inclusive education practices for students with disabilities, and this has a strong effect on "virtually all critical aspects of [special education] teachers' working conditions" (Gersten, Keating, Yovanoff, \& Harniss, 2001, p. 557). The principal's values and supportive actions, as mediated by overall school culture, influence special educators' sense of administrative support and confidence in their own ability to make a difference in the academic lives of their students (Billingsley, 1993; Brownell \& Smith, 1993; Carlson \& Billingsley, 2001; Rea, McLaughlin, \& Walther-Thomas, 2002). Similar findings have been reported in research related to teacher attitudes (Cook, Semmel, \& Gerber, 1999; National Association State Boards of Education [NASBE], 1992; Stanovich \& Jordan, 1998) and teacher attrition (e.g., Billingsley \& Cross, 1991; Boe et al., 1999; Gonzalez, 1996; Miller et al., 1999; S. D. Whitaker, 2000).

Building leadership also affects the extent to which teachers use proven, research-based practices to improve student performance (Embich, 2001; Noell \& Witt, 1999). When school leaders focus on fundamental instructional issues, demonstrate strong support for special education, and provide ongoing professional development, academic outcomes for students with disabilities and others at risk improve (Benz, Lindstrom, \& Yovanoff, 2000; Brownell, Ross, Colon, \& McCallum, 2003; Kearns, Kleinert, Clayton, Burdge, \& Williams, 1998; Klingner, Arguelles, Hughes, \& Vaughn, 2001).

The job of an effective principal is multifaceted, and two key areas must receive high leadership attention and support:
1. Principals must develop, enhance, and monitor the professional skills and knowledge of their faculty.

2. Principals must work with their communities to create a common cluster of expectations promoting implementation of those skills and knowledge.

Competent leadership requires holding various components of the school together in a productive and dynamic relationship with one another, and holding individuals accountable for their contributions to common goals (Council of Chief State School Officers [CCSSO], 1996; Elmore, 2000; Tschannen-Moran, 2004). In this article we explore five dimensions of effective leadership by principals. Effective special education services depend on the ability and willingness of school leaders to (a) promote an inclusive school culture; (b) provide instructional leadership; (c) model collaborative leadership; (d) manage and administer organizational processes; and (e) build and maintain positive relations with teachers, families, and the community.

\section{Promoting an Inclusive School Culture}

In developing an inclusive school culture, effective leaders see themselves as stewards of the process (Burrello \& Lashley, 1992; NAESP, 2001a, 2001b; NASBE, 1992; NCD, 1995; NRC, 1997; NSDC, 2001). Effective principals understand the importance of a school context that supports academic achievement for all students, including those with disabilities.

Principals who genuinely believe that their school mission is academic success for all communicate this value to their constituents. Their "values, beliefs, and personal characteristics inspire people to accomplish the school's mission" (NAESP, 2001b, p. 19). As the prime shapers of school culture, principals must set norms that are founded on the value of academic effort and support for the achievement of all students. If student achievement improves over time, it is, in large measure, because key stakeholders share the leader's vision for student success based on common values, traditions, and beliefs (Deal \& Peterson, 1999).

Effective administrators are committed to continuous improvement in their schools, tempered by a thorough understanding of the complexities of organizational change (Kouzes \& Posner, 1995; Loucks-Horsley, \& Roody, 1990; Wasley, Hampel, \& Clark, 1997). They understand the necessity of winning solid support for new initiatives. Without it, they know that their best efforts will produce few results (Heifetz, 1994; Ikeda, Tilly, Stumme, Volmer, \& Allison, 1996). As the prime influence on school culture, good leaders listen effectively to stakeholders' suggestions, questions, and concerns. They respect their community's values and beliefs, and they engage others in developing a coherent vision of student success (Deal \& Peterson, 1999; Lipp, 
1992; Tschannen-Moran, 2004). In brief, effective leaders define themselves as advocates and change agents with a mission to increase their community's capacity to deliver academic success (Ashby \& Krug, 1998; Fullan, 2003; Gupton, 2003).

Because culture evolves as the school team works to solve problems, principals improve school functioning by consciously developing leadership potential in others and actively engaging community members in finding new solutions to old problems (Schein, 1992). Schools that embrace significant changes participate in ongoing "reculturing," in which new expectations, structures, and patterns emerge to support initiatives (Fullan, 2001, p. 44). The principal plays a critical role as facilitator in reculturing efforts (Kouzes \& Posner, 1995; Sergiovanni, 1992). The principal's commitment and leadership provides reassurance to teachers, students, specialists, and others about the value of their efforts (Fullan \& Stiegelbauer, 1991; Hall \& Hord, 1987). Principals help reinforce and recognize stakeholders' contributions. Their ongoing words and actions demonstrate their personal investment and their willingness to do whatever it takes to provide the best education possible for their students.

\section{Providing Instructional Leadership}

The importance of instructional leadership in developing effective schools has been widely documented (Barth et al., 1999; CCSSO, 1998; Gates, Ross, \& Brewer, 2001; Institute for Educational Leadership [IEL], 2000; Purkey \& Smith, 1983). Principals play pivotal roles in high-risk learning environments that address complex student achievement issues (Brookover, Erickson, \& McEvoy, 1996; Edmonds, 1979; Wellisch, MacQueen, Carriere, \& Duck, 1978). Although much of this literature does not refer specifically to special education (e.g., National Commission on Excellence in Education [NCEE], 1983), its relevance is clear (Crockett, 2002, 2004; Lashley \& Boscardin, 2003; NASBE, 1992; Vernon, 2003).

As skillful instructional leaders, principals ensure that their schools focus on powerful academic outcomes for all learners (Council for Exceptional Children [CEC], 1997; Gupton, 2003; Klingner et al, 2001; NCTAF, 1996). Their actions promote a culture of disciplined professional inquiry dedicated to research-based practices and data-based decisions (Fullan, 2003). They are continually apprised of current research and are knowledgeable about research on academic and behavioral intervention. They set knowledge and skill expectations for faculty and facilitate contextual learning opportunities to assure continuous professional improvement in their buildings.

For example, many principals support small, topical reading groups for teachers and specialists that allow interested participants to explore topics of common interest or need. Typically, groups are small and participation is voluntary. Although some are based on grade-level or department teaching assignments, many develop out of common professional interests, school goals, or classroom needs. The groups select a book or a series of articles, and the school provides all reading materials. Realistic reading goals are set, and the groups meet once or twice a month to discuss the material and possible implications for their own practice. When the groups finish the books, they provide brief oral or written reports at faculty meetings, via email, or on the school's website.

In some schools, interested group members continue to explore their topic together throughout the year. In others, new topical groups are established quarterly. Principals who are committed to reading groups support these efforts with school or district professional development funds, community grants, PTA fundraisers, or contributions from business partners.

Clearly, instructional leaders who understand students with disabilities, IDEA and NCLB requirements, and effective practice are better prepared to provide students and their teachers with appropriate classroom support. They recognize the importance of comprehensive academic planning, ongoing monitoring of progress, and data-based decisions regarding students' programs. They have the knowledge, skills, and commitment to facilitate academic and structural integrity in classrooms so that students, teachers, specialists, paraprofessionals, and others can work effectively.

For example, good leaders understand that classroom heterogeneity is the foundation of inclusive education, and they refuse to allow a few classrooms to become academic "dumping grounds" for students with the most challenging academic needs. They work closely with their teams to create balanced classroom rosters, manageable caseload responsibilities, and appropriate in-class support for students and teachers. They know that most traditional responses to academic failure-such as pull-out programs, whole-class ability grouping, and grade retention-do not work well (Shepard \& Smith, 1990). Good leaders work proactively with their teams to develop more effective student- and site-specific responses to low performance (Crockett, 2002; Gersten et al., 2001; Gonzalez, 1996; Keefe \& Jenkins, 2002; Wald, 1998). In one way or another, all of the actions of effective principals are geared toward providing teachers and specialists with the resources and support they need to do their jobs effectively (Bateman \& Bateman, 2001; Pankake \& Fullwood, 1999; Sage \& Burrello, 1994; Thomas, Correa, \& Morsink, 2001).

Effective instructional leadership is based on knowledge and skills that permit a deep understanding of what is happening in every classroom. Good principals work directly 
with teachers and students. By spending time in class, they learn about individual and schoolwide professional development needs. They thoughtfully analyze student and teacher performance and address instructional issues directly to promote classroom quality. Through formal (e.g., workshops) and informal (e.g., one-on-one coaching) means, skillful principals help their faculty and staff develop effective teaching, management, and decision-making skills (Crockett, 2002).

They do so while preserving the dignity of the faculty and their trust in school leadership. In these settings, teachers can modify classroom practices and conform to the principal's expectations without compromising their standing in the school community (Deal \& Peterson, 1999; Thomas et al., 2001).

Effective principals know how to create school structures that support professional knowledge-building and knowledge-sharing. They understand that, when adults learn in context, new knowledge and skills are more specific and more readily usable (Fullan, 2001, p. 105). Contextual learning is based on the premise that "what is gained as a group must be shared as a group" (Pasclae, Millemann, \& Gioja, 2000, p. 264). Schools that value continuous learning are often referred to as "professional learning communities." In these schools, leaders provide ongoing formal and informal opportunities for adults to learn together and from each other. By recognizing local expertise and providing opportunities for master teachers to share their knowledge and skills (e.g., weekly "walk and talk" groups, monthly "guest lecture" seminars, classroom observations, systematic new teacher mentoring and induction, and sponsored "lunch and learn" sessions), principals ensure that professional development efforts make sense within the context of their schools (Walther-Thomas, Korinek, \& McLaughlin, 1999).

When practitioners engage in meaningful professional development, reflective practice, and collaboration with others, school teams can develop a coherent set of standardsdriven goals that are linked to their common mission of student success (Newman \& Simmons, 2000). In these settings, participants develop greater trust and respect for one another, and are more likely to take risks (Hughes, 1999; Tschannen-Moran, 2004). Over time, cohesive cultures achieve a level of synergy that strengthens local efforts and commitments to shared leadership (Fullan, 2003; Sergiovanni, 1992).

School climate is another facet of school culture that is more easily measured than other dimensions. In schools with a positive climate, teachers understand school goals and feel genuinely connected to the school's mission. Initial compliance becomes commitment (Tschannen-Moran, 2004). Unless the school climate is strong and supported by a commitment to teamwork, high levels of academic performance are difficult, if not impossible, to achieve (Hoyle, English, \& Steffy, 1994). Research on school climate supports the contention that it makes a difference in student achievement (Tschannen-Moran, Parrish, \& DiPaola, 2003).

Schools with positive, open climates nurture teachers who become confident about their own abilities and the school's effectiveness in helping students learn. These schools reap many benefits. Faculty exhibits higher levels of trust (Hoy \& Tschannen-Moran, 1999; Tarter, Sabo, \& Hoy, 1995 ) and participation in decision-making (Sabo, Barnes, \& Hoy, 1996). School effectiveness (Hoy \& Sabo, 1998; Hoy, Tarter, \& Kottkamp, 1991), collaboration and use of inclusive practices (Rea et al., 2002), organizational flexibility, and collegial self-governance (Glickman, 2002) are elevated.

\section{Modeling Collaborative Leadership}

As schools become more inclusive, they are also becoming more collaborative (Boyer \& Lee, 2001; WaltherThomas et al., 2000). To educate diverse learners effectively in general education classrooms, stakeholders must work closely with one another to develop, implement, and evaluate comprehensive instructional programs. Through a process of ongoing collaboration, effective school teams reach an alignment between learning goals and instruction, effective progress monitoring, and appropriate student and teacher support (Crockett, 2004).

In many schools, educators are being asked to redefine their roles and responsibilities to create more responsive learning communities that support academic success for all. Unfortunately, many are poorly prepared for this challenge. Few university preparation programs adequately prepare teachers to work with other adults. Highly qualified context specialists often lack the interpersonal skills needed to collaborate effectively with colleagues and families (Thomas et al., 2001; Walther-Thomas et al., 2000). Consequently, principals have to be effective role models for collaboration and communication to ensure that academic and social support networks are established in their schools (DiPaola \& Walther-Thomas, 2003; NAESP, 2001b).

When leaders possess effective interpersonal skills and consciously guide the communication skills development of others, they ensure that their teams have the knowledge, skills, and disposition needed to work successfully with others and address complex challenges (Bateman \& Bateman, 2001; Collins, 2002; Gates et al., 2001; Kearns et al., 1998; Klingner et al., 2001; Sage \& Burrello, 1994). Successful collaboration is built on a solid foundation of interpersonal communication skills, trust, and mutual respect (TschannenMoran, 2004). When school leaders actively and effectively engage their community in problem solving, their schools are strengthened because they tap "rich resources of varied 
talent and skill that can only come from team-based leadership" (Gupton, 2003, p. vii). They mobilize others by continuously reshaping and improving programs that will meet instructional goals and address emerging needs (Deal \& Peterson, 1999).

As collaborative leaders, principals must "talk the inclusive school talk" daily but, more important, they must be prepared to "walk the talk" and thereby insure that fundamental changes are implemented, effective support services are provided, progress is monitored closely, and school momentum is maintained. To do so, there must be consistency between what leaders say about their school's reform needs and what they do to create lasting improvement.

For example, an enthusiastic principal promises to provide her co-teachers with better support the following year. Their faith in her leadership will erode quickly if there is discontinuity between her words and her willingness to make available the needed structural supports, such as professional development sessions that focus on co-teaching and team planning (Walther-Thomas et al., 2000).

\section{Managing and Administering Organizational Processes}

Competent leaders are also effective school managers. As such, they cultivate what Collins (2002) referred to as "a culture of discipline," in which productive engagement in the work (i.e., teaching and learning) is the expectation for all stakeholders, so every person's contribution counts. If the principal convinces all of his or her constituents (students, teachers, paraprofessionals, administrative assistants, cafeteria workers, custodians, families, community partners) that they have important teaching and learning responsibilities, inclusive and supportive networks emerge.

Clearly, creating inclusive schools and corresponding support networks is a labor-intensive proposition. Principals can't do it alone. As effective managers, they must identify needs (e.g., hearing interpreters, better transition planning, specialized software), find appropriate resources (e.g., reference books, mentors, professional development workshops, a schoolwide behavior plan), and delegate implementation duties (Deal \& Peterson, 1999; Embich, 2001; Gersten et al., 2001).

Even when resources are limited, good school managers find ways to meet critical needs. They analyze data effectively and enlist others to work with them to find creative ways by which to redistribute resources more effectively. For example, in one school where co-teachers did not have dedicated co-planning time, the school-improvement team generated a list of options. Following a discussion with PTA officers, the team used money generated from a successful fund-raising event to hire a "floating" substitute teacher once a week for the remainder of the school year. This arrangement provided 10 co-teaching teams (i.e., classroom teachers and their teaching partners-special educators, reading specialists, occupational therapists, and speech and language therapists) with 75 minutes of biweekly planning time. The following year, the principal received increased substitute teacher funds from the superintendent to provide weekly planning time for all teams (Walther-Thomas et al., 2000).

Schools built on models of collaboration and organizational citizenship operate more efficiently than those based on more hierarchical approaches. When principals engage in collaborative leadership and develop confidence in others' skills, they spend less time justifying their decisions and investigating others' actions (DiPaola \& Tschannen-Moran, 2001). They build a culture of trust and earn the efficiency benefits of a trusting environment.

By focusing on collaborative problem solving rather than on control, they demonstrate both trust and flexibility. Setting clear expectations for faculty and staff and treating them with professional respect and courtesy means that fewer personnel rules will be needed. In finding the proper balance in handling policies, rules, and procedures, successful principals do not abuse their administrative power through manipulation or through strict interpretation of rules (Tschannen-Moran, 2004).

\section{Building and Maintaining Effective Working Relationships}

According to Fullan (2001), relationships are the essential ingredient in all successful change initiatives. "If relationships improve, things get better. If they remain the same or get worse, ground is lost. Thus, effective school leaders must be consummate relationship builders with diverse people and groups" (p. 5). Effective principals seek diverse input on important school matters, listen thoughtfully to the opinions of their students, families, school personnel, and community leaders, and make well-informed decisions (Foley \& Lewis, 1999; Klingner et al., 2001). Effective leaders increase the "social capital" of their schools (Coleman, 1988) as stakeholders work together for the academic benefit of students (Wasley et al., 1997; Tschannen-Moran, 2004; Thomas et al., 2001).

As noted earlier, novice administrators are often charged with responsibility for special education. Their success in cultivating good working relationships with the families of students with disabilities is an essential part of effective special education services (Bateman \& Bateman, 2001; Gersten et al., 2001; Miller et al., 1999). Given a broad array of complex and emotionally charged issues (e.g., student and family needs, achievement concerns, competing values and expectations, limited state and local resources, IDEA and NCLB legal mandates), school leaders must take the time to know students and their families and the laws pertaining to 
students with disabilities. They need to be familiar with useful family resources in the district, community, and state.

Given the nature of the work, some conflict, frustration, and inadvertent miscommunication is inevitable. Effective principals possess the interpersonal skills and disposition needed to deal with conflict, solve problems amicably, and repair trust through informal and formal processes that promote the success of students with disabilities (Deal \& Peterson, 1999; Tschannen-Moran, 2004). In situations where home-school relationships become frayed, capable leaders must be willing to promote the vision that repair is possible.

When trust breaks down, effective school leaders serve the important mediator role, that provides members of the school community with a trusted resource in the midst of conflict (Billingsley, 2004). Skillful mediation can prevent conflict when members of the school community are supported by norms and processes designed to negotiate solutions that meet the needs of all parties (Thomas et al., 2001).

Competent leaders develop and sustain effective learning communities by making sure the faculty, staff, and students have the support and resources they need to be successful (Glickman, 2002). They facilitate inquiry, collaboration, reflection, and analysis to guarantee student achievement, professional growth, and continuous program improvement (Gupton, 2003). They work proactively to avoid conflict by maintaining a variety of structures designed to facilitate ongoing home-school communication such as homework "hotlines," electronic newsletters, "family fun nights," family education seminars, and home visits.

In sum, good principals are the best hope that students with disabilities and others at risk for school failure have for academic success in this NCLB era. Capable school leaders, who embrace their academic mission and have effective leadership and management skills, must be champions for their students, families, and teachers (Brownell et al., 2003; DiPaola \& Walther-Thomas, 2003). They must promote the development of dynamic learning communities based on common student achievement goals that guide all school efforts. Most important, instructional leaders must ensure that all students have teachers who are well prepared to meet diverse needs and who have the support to teach effectively (Hughes, 1999; Klingner et al., 2001; NAESP, 2001a; Stanovich \& Jordan, 1998).

\section{PREPARING PRINCIPALS FOR SPECIAL EDUCATION LEADERSHIP}

Given the complexity of their roles and responsibilities, it is not surprising that many principals feel poorly prepared for jobs as special education leaders in their buildings (Bateman \& Bateman, 2001; Crockett, 2002; DiPaola \& WaltherThomas, 2003). Most lack sufficient coursework and field experience (DiPaola \& Tschannen-Moran, 2003; Katsiyannis, Conderman, \& Franks, 1996; Parker \& Day, 1997). Many report the need for additional knowledge and skills to help them facilitate development, implementation, and evaluation of appropriate programs and support systems for these students. In one study, principals identified help and information about implementing successful special education programs as their greatest need (DiPaola \& TschannenMoran, 2003).

Although specific duties associated with the special education process vary from district to district, in general, principals hold the key to school-level compliance (Lashley \& Boscardin, 2003; Sage \& Burrello, 1994). Effective principals must be familiar with the district and community resources needed to provide appropriate education for students with unique learning needs (Hughes, 1999; Pankake \& Fullwood, 1999). Inadequately prepared administrators cannot facilitate special education services in their buildings.

New principals, in particular, are challenged by the complexity of special education roles and responsibilities (Bateman \& Bateman, 2001). One of the primary administrative responsibilities of novice administrators is to oversee special education. New building administrators often find themselves "suddenly thrust into situations in which they must be the final arbiter on matters related to strange-sounding issues such as IEPs, 504 decisions, due process hearings, and IDEA compliance" (CEC, 2001, p. 1). They are forced to learn on their own - or, in many cases, rely on the knowledge and skill of others who may or may not be wellinformed coaches.

In the best-case scenarios, novice administrators are well prepared for special education leadership as a result of previous teaching experience and advanced preparation. Comprehensive preparation facilitates a strong, working knowledge of IDEA policies and procedures, a good understanding of disabilities and some of the unique learning and behavior challenges various conditions present, and a comprehensive knowledge of research-based practices (e.g., positive behavior support, direct instruction, learning strategies, content enhancements; Crockett, 2002). Once new principals are on the job, systematic mentoring at both district and building levels helps familiarize them with existing organizational expectations and district resources, procedures, and processes related to ongoing communication and collaboration (e.g., chain of command, collaborative structures, communication flowcharts; Lashley \& Boscardin, 2003).

State and local agencies must provide building leaders with easy access to useful information such as new legislative action, case law precedents, changes in regulations, relevant research, online resources, and information about upcoming professional development opportunities (Crockett, 2004; Gates et al., 2001; Strahan, 1999; Turnbull \& 
Cilley, 1999). When school systems provide a comprehensive special education induction program for new administrators, it conveys a powerful message regarding the importance that district leadership places on services for students with disabilities (Bateman \& Bateman, 2001; NAESP, 2001a, 2001b).

Given the rapidly increasing shortage of principals, innovative leadership preparation programs are emerging (DiPaola \& Walther-Thomas, 2003), many of which are designed to recruit experienced special educators, related services personnel, and general educators with strong special education experience. These students enter administrative leadership programs with expertise based on experience as teachers, program planners, collaborators, and members of problem-solving teams.

For example, two federally funded leadership projects at the University of Kansas are preparing masters-level and doctoral-level students (e.g., teachers, school psychologists, counselors, social workers) for building and district leadership positions. Based on their previous experience and completion of degree programs that emphasize special education leadership, program graduates, as principals and school superintendents, will be well prepared to advocate for students with disabilities and others at risk. Their prior knowledge and skills, complemented by advanced professional training and guided on-the-job experiences, will facilitate the development and delivery of more effective special education services (Skrtic, Kleinhammer-Tramill, \& WaltherThomas, 2003).

\section{CONCLUSION}

Ensuring appropriate educational opportunities for students with disabilities is one of the greatest challenges that public schools face. Research suggests that few school leaders are prepared to provide effective special education leadership (Monteith, 2000; Walther-Thomas, DiPaola, \& Butler, 2002). If school reform goals are to be realized, effective leaders must be prepared to address diverse learning needs. It is incumbent on universities, professional organizations, and public schools to determine how best to prepare and support principals in their efforts to meet rising public expectations.

More research is needed to examine the nature of the role of the principal itself, improve the preparation process, and explore alternative school leadership models. Preparation must emphasize the development of leadership skills that enable principals to organize their schools in ways that capitalize on the collective professional skills, knowledge, and experiences of stakeholders (Gupton, 2003; Hughes, 1999). By doing so, school leaders can create better learning environments for all students and more productive and satisfying work environments that remain focused on instructional improvement and community engagement (Heifetz, 1994; Kouzes \& Posner, 1995).

Providing appropriate educational opportunities for all students is a lofty goal. Neither legislative mandates, such as NCLB, nor noble intentions can guarantee better educational outcomes for all students. To fulfill the goal of leaving no child behind in today's school reform, capable and caring leaders are needed in every school. Without capable instructional leaders as dedicated advocates for students and teachers and skillful community builders, current reform efforts will fail and NCLB's ambitious goals will not be achieved. To achieve true school reform, effective leadership must become a reality in every school across the country.

This manuscript was based, in part, on the DiPaola and Walther-Thomas (2003) issues brief (COPSSE Document No. IB-7E) prepared for the Center on Personnel Studies in Special Education (http://copsse.org) funded by the U.S. Office of Special Education Programs (OSEP).

\section{REFERENCES}

Ashby, D. E., \& Krug, S. E. (1998). Thinking through the principalship. Larchmont, NY: Eye on Education.

Barth, P., Haycock, K., Jackson, H., Mora, K., Ruiz, P., Robinson, S., \& Wilkins, A. (1999). Dispelling the myth: High poverty schools exceeding expectations. Washington, DC: Education Trust.

Bateman, D., \& Bateman, C. F. (2001). A principal's guide to special education. Arlington, VA: Council for Exceptional Children.

Benz, M. R., Lindstrom, L., \& Yovanoff, P. (2000). Improving graduation and employment outcomes of students with disabilities: Predictive factors and student perspectives. Exceptional Students; 66, 509-529.

Billingsley, B. S. (1993). Teacher retention and attrition in special education: A critical review of the literature. Journal of Special Education, $27,137-174$.

Billingsley, B. S. (2004). Promoting teacher quality and retention in special education. Journal of Learning Disabilities, 37, 370-376.

Billingsley, B. S., Carlson, E., \& Klein, S. (2004). The working conditions and induction support of early career special educators. Exceptional Children, 70(3), 333-347.

Billingsley, B. S., \& Cross, L. H. (1991). Teachers' decisions to transfer from special to general education. Journal of Special Education, 24, 496-511.

Boe, E. E., Barkanic, G., \& Leow, C. S. (1999). Retention and attrition of teachers at the school level: National trends and predictors (Data Analysis Report No. 1999-DAR1). Philadelphia: University of Pennsylvania, Center for Research and Evaluation in Social Policy.

Boyer, L., \& Lee, C. (2001). Converting challenge to success: Supporting a new teacher of students with autism. The Journal of Special Education, 35, 75-83.

Brookover, W. B., Erickson, F. J., \& McEvoy, A. W. (1996). Creating effective schools: An in-service program for enhancing student learning, climate and achievement (Rev. ed.). Holmes Beach, FL: Learning Publications.

Brownell, M. T., Ross, D. R., Colon, E.P., \& McCallum, C. L. (2003). Critical features of special education preparation: A comparison with exemplary practices in general teacher education. (COPSSE Document No. RS-4E). Gainesville, FL: University of Florida, Center on Personnel Studies in Special Education. 
Brownell, M. T., \& Smith, S. W. (1993). Understanding special education attrition: A conceptual model and implications for teacher education. Teacher Education and Special Education, 16, 270- 282.

Burrello, L. C., \& Lashley, C. (1992). On organizing the future: The destiny of special education. In K. Waldron, A. Riester, \& J. Moore (Eds.), Special education: The challenge for the future (pp. 64-95). San Francisco: Edwin Mellen Press.

Carlson, E., \& Billingsley, B. S. (2001, July). Working conditions in special education: Current research and implications for the field. Paper presented at OSEP Project Directors' Conference, Washington, DC.

Coleman, J. S. (1988). Social capital in the creation of human capital. American Journal of Sociology, 94, 95-120.

Collins, J. (2002). Good to great: Why some companies make the leap and others don't. New York: Harper Business.

Cook, B. G., Semmel, M. I., \& Gerber, M. M. (1999). Attitudes of principals and special education teachers toward the inclusion of students with mild disabilities: Critical differences of opinion. Remedial and Special Education, 20, 199-207.

Council for Exceptional Children (CEC). (1997). IDEA 1997: Let's make it work. Arlington, VA: Author.

Council for Exceptional Children (CEC). (2001). Implementing IDEA: A guide for principals. Arlington, VA: Author.

Council of Chief State School Officers (CCSSO). (1996). Standards for school leaders. Washington, DC: Author.

Council of Chief State School Officers (CCSSO). (1998). Propositions for quality professional development for school administrators. Washington, DC: Author.

Crockett, J. B. (2002). Special education's role in preparing responsive leaders for inclusive schools. Remedial and Special Education, 23, 189-199.

Crockett, J. B. (2004). Taking stock of science in the schoolhouse: Four ideas to foster effective instruction. Journal of Learning Disabilities, 37, 189-199.

Deal, T. E., \& Peterson, K. D. (1999). Shaping school culture: The heart of leadership. San Francisco: Jossey-Bass.

DiPaola, M. F. \& Tschannen-Moran, M. (2001). Organizational citizenship behavior in schools and its relationship to school climate. Journal of School Leadership, 11, 424-447.

DiPaola, M. F. \& Tschannen-Moran, M. (2003). The principalship at a crossroads: A study of the conditions and concerns of principals. NASSP Bulletin, 87 (634), 43-65.

DiPaola, M. F., \& Walther-Thomas, C. (2003). Principals and special education: The critical role of school leaders (COPSSE Document No. IB-7E). Gainesville, FL: University of Florida, Center on Personnel Studies in Special Education.

Edmonds, R. (1979). Effective schools for the urban poor. Educational Leadership, 37, 15-27.

Elmore, R. F. (2000, Winter). Building a new structure for school leadership. Washington, DC: Albert Shanker Institute.

Embich, J. L. (2001). The relationship of secondary special education teachers' roles and factors that lead to professional burnout. Teacher Education and Special Education, 24, 58-69.

Foley, R. M., \& Lewis, J. A. (1999). Self-perceived competence of secondary principals to serve as school leaders in collaborative-based educational delivery systems. Remedial \& Special Education, 20, 233-243.

Fullan, M. (2001). Leading in a culture of change. San Francisco: Jossey-Bass. Fullan, M. (2003). The moral imperative of school leadership. Thousand Oaks, CA: Corwin.

Fullan, M., \& Stiegelbauer, S. (1991). The new meaning of educational change. New York: Teachers College Press.
Gates, S., Ross, K., \& Brewer, D. (2001). Leading to reform: Educational leadership for the 21st century. Oak Brook, IL: North Central Regional Educational Laboratory.

Gersten, R., Keating, T., Yovanoff, P., \& Harniss, M. K. (2001). Working in special education: Factors that enhance special educators' intent to stay. Exceptional Students, 67, 549-453.

Giacobbe, A. C., Livers, A. F., Thayer-Smith, R., \& Walther-Thomas, C. (2001). Raising the academic standards bar: What states are doing to measure the performance of students with disabilities. Journal of Policy Studies, 12, 10-17.

Glickman, C. D. (2002). Leadership for learning: How to help teachers succeed. Alexandria, VA: Association for Supervision and Curriculum Development.

Gonzalez, P. (1996). Causes and cures of teacher attrition: A selected bibliography focusing on special educators. National Association of Directors of Special Education, Alexandria VA. (ERIC Document Reproduction Service No. ED 389 128)

Gupton, S. (2003). The instructional leadership toolbox: A handbook for improving practice. Thousand Oaks, CA: Corwin Press.

Hall, G. E., \& Hord, S. M. (1987). Change in schools: Facilitating the process. New York: State University of New York Press.

Heifetz, R. (1994). Leadership without easy answers. Cambridge, MA: Harvard University Press.

Hoy, W. K., \& Sabo, D. J. (1998). Quality middle schools: Open and healthy. Thousand Oaks, CA: Corwin.

Hoy, W. K., Tarter, C. J., \& Kottkamp, R. B. (1991). Open schools/healthy schools: Measuring organizational climate. Beverly Hills, CA: Sage.

Hoy, W. K., \& Tschannen-Moran, M. (1999). Five faces of trust: An empirical confirmation in urban elementary schools. Journal of School Leadership, 9, 184-208.

Hoyle, J., English, F., \& Steffy, B. (1994). Skills for successful school leaders (2nd ed.). Arlington, VA: American Association of School Administrators.

Hughes, L. W. (1999). The leader: Artist? Architect? Commissar? In L. W. Hughes (Ed.), The principal as leader (2nd ed., pp. 3-24). Upper Saddle River, NJ: Merrill/Prentice Hall.

Ikeda, M. J., Tilly, W. D., Stumme, J., Volmer, L., \& Allison, R. (1996). Agency-wide implementation of problem solving consultation: Foundations, current implementation, and future directions. School Psychology Quarterly, 11, 228-243.

Institute for Educational Leadership (IEL). (2000). Leadership for student learning: Reinventing the principalship. Washington, DC: A Report of the Task Force on the Principalship.

Katsiyannis, A., Conderman, G., \& Franks, D. J. (1996). State practices on inclusion: A national review. Remedial and Special Education, 16, 279-287.

Kearns, J. F., Kleinert, H. L., Clayton, J., Burdge, M., \& Williams, R. (1998). Principal supports for inclusive assessment: A Kentucky story. Teaching Exceptional Children, 31(2), 16-23.

Keefe, J. M., \& Jenkins, J. W. (2002). Two schools: Two approaches to personalized learning. Phi Delta Kappan, 83, 449-456.

Klingner, J. K., Arguelles, M. E., Hughes, M. T., \& Vaughn, S. (2001). Examining the school-wide "spread" of research-based practices. Learning Disability Quarterly, 24, 221-234.

Kouzes, J. M., \& Posner, B. Z. (1995). The leadership challenge. San Francisco: Jossey-Bass.

Lashley, C., \& Boscardin, M. L. (2003). Special education administration at a crossroads: Availability, licensure, and preparation of special education administrators. (COPSSE Document No. IB- 8E). Gainesville, FL: Center on Personnel Studies in Special Education.

Lipp, M. (1992). An emerging perspective on special education: A development agenda for the 1990s. Special Education Leadership Review, $1,10-39$. 
Loucks-Horsley, S., \& Roody, D. S. (1990). Using what is known about change to inform the regular education initiative. Remedial and Special Education, 11, 51-56.

Miller, M. D., Brownell, M. T., \& Smith, S. W. (1999). Factors that predict teachers staying in, leaving, or transferring from the special education classroom. Exceptional Students, 65, 201-218.

Monteith, D. S. (2000). Professional development for administrators in special education: Evaluation of a program for underrepresented personnel. Teacher Education and Special Education, 23, 281-289.

National Association of Elementary School Principals (NAESP). (2001a). Essentials for principals: School leader's guide to special education. Alexandria, VA: Author.

National Association of Elementary School Principals (NAESP). (2001b). Leading learning communities: NAESP standards for what principals should know and be able to do. Alexandria, VA: Author.

National Association of Elementary School Principals (NAESP) \& ILIAD Project (2001). Implementing IDEA: A guide for principals. Arlington, VA: Council for Exceptional Students and Alexandria, VA: National Association of Elementary School Principals.

National Association State Boards of Education (NASBE). (1992). Winning ways: Creating inclusive schools, classrooms, and communities. Alexandria, VA: Author.

National Center for Education Statistics (NCES). (2003). Institute of Education Services, U.S. Department of Education, Washington, DC.

National Commission on Excellence in Education (NCEE). (1983). A nation at risk: The imperative for educational reform. Washington, DC: Author.

National Commission on Teaching and America's Future (NCTAF). (1996). What matters most: Teaching for America's future. New York: Author.

National Council on Disability (NCD). (1995). Improving the implementation of the Individuals with Disabilities Act: Making schools work for all of America's students. Washington, DC: Author.

National Research Council (NRC). (1997). Educating one and all: Students with disabilities and standards-based reform. Washington, DC: National Academy Press.

National Staff Development Council (NSDC). (2001). Learning to lead, leading to learn: Improving school quality through principal professional development. Oxford: $\mathrm{OH}$, Author.

Newman, M., \& Simmons, W. (2000). Leadership for student learning, Phi Delta Kappan, 82(1), 9-12.

Noell, G. H., \& Witt, J. C. (1999). When does consultation lead to intervention implementation? Journal of Special Education, 33, 29-41.

Pankake, A. M., \& Fullwood, H. L. (1999). "Principals of inclusion": Things they need to know and do. Catalyst for Change, 28, 25-26.

Parker, S. A., \& Day, V. P. (1997, March). Promoting inclusion through instructional leadership: The roles of the secondary school principal. NASSP Bulletin, 83-89.

Pasclae, R., Millemann, M., \& Gioja, L. (2000). Surfing the edge of chaos. New York: Crown Business.

Purkey, S. C., \& Smith, M. S. (1983). Effective schools: A review. Elementary School Journal, 83, 427-452.

Rea, P. J., McLaughlin, V. L., \& Walther-Thomas, C. S. (2002). A comparison of outcomes for middle school students with learning disabilities in inclusive and pullout programs. Exceptional Students 68, 203-222.

Sabo, D., Barnes, K., \& Hoy, W. K. (1996). Organizational health and decision participation: An empirical analysis of healthy interpersonal dynamics and teacher participation. Journal of School Leadership, 6, 576-599.

Sage, D., \& Burrello, L. (1994). Leadership in educational reform: An administrator's guide to changes in special education. Baltimore: Paul H. Brookes.

Schein, E. H. (1992). Organizational culture and leadership (2nd ed.). San Francisco: Jossey- Bass.
Sergiovanni, T. J. (1992). Moral leadership: Getting to the heart of school improvement. San Francisco: Jossey-Bass.

Shepard, L., \& Smith, M. (1990). Synthesis of research on grade retention. Educational Leadership, 47, 84-88.

Skrtic, T., Kleinhammer-Tramill, J., \& Walther-Thomas, C. (2003). Building administration for special education services (BASES). Washington, DC: U.S. Department of Education, Office of Special Education Programs, Leadership Personnel Preparation Program. (H325D030040)

Stanovich, P. J., \& Jordan, A. (1998). Canadian teachers' and principals' beliefs about inclusive education as predictors of effective teaching in heterogeneous classrooms. Elementary School Journal, 98, 221-238.

Strahan, R. D. (1999). Building leadership and legal strategies. In L. W. Hughes (Ed.), The principal as leader (2nd ed., pp. 291-322). Upper Saddle River, NJ: Merrill/Prentice.

Tarter, C. J., Sabo, D., \& Hoy, W. K. (1995). Middle school climate, faculty trust, and effectiveness. Journal of Research and Development in Education, 29, 41- 49.

Thomas, C. C., Correa, V. I., \& Morsink, C. V. (2001). Interactive teaming: Enhancing programs for students with special needs (3rd ed.). Columbus, OH: Merrill Prentice Hall.

Thurlow, M. (2000). Standards-based reform and students with disabilities: Reflections on a decade of change. Focus on Exceptional Students, 32(1). Retrieved March 8, 2002, from Expanded Academic ASAP database.

Tschannen-Moran, M. (2004). Trustworthy leadership: The heart of productive schools. San Francisco: Jossey-Bass.

Tschannen-Moran, M., Parrish, J., \& DiPaola, M. F. (2003). School climate and state standards: How interpersonal relationships influence student achievement. Working paper at the College of William and Mary. Available at http://mxtsch.people.wm.edu/.

Turnbull, H. R., \& Cilley, M. (1999). Explanations and implications of the 1997 Amendments to IDEA. Upper Saddle River, NJ: Merrill/Prentice.

U. S. Department of Education (USDOE). (1997). The Individuals with Disabilities Education Act [IDEA](PL 105-17).

U.S. Department of Education (USDOE). (2002). No Child Left Behind: ESEA Reform. Washington, DC: Author.

Vernon, L. J. (2003). Collaborative practices in schools: The impact of school-based leadership teams on inclusive education. Unpublished doctoral dissertation, College of William and Mary.

Vernon, L., Baytops, J., McMahon, P., Holland, D., \& Walther-Thomas, C. (2002). Graduation requirements and students with disabilities: A review of state practices.(Under review.)

Wald, J. L. (1998). Retention of special education professionals: A practical guide of strategies and activities for educators and administrators. Reston, VA: National Clearinghouse for Professionals in Special Education.

Walther-Thomas, C. S., DiPaola, M. F., \& Butler, A. J. (2002). A national study of endorsement requirements for principals: No wonder they don't understand special education. Unpublished research.

Walther-Thomas, C., Korinek, L., \& McLaughlin, V. L. (1999). Collaboration for student success. Focus on Exceptional Children, 32, 1-18.

Walther-Thomas, C. S., Korinek, L., McLaughlin, V. L., \& Williams, B. (2000). Collaboration for effective inclusive education: Developing successful programs. Boston: Allyn \& Bacon.

Wasley, P., Hampel, R., \& Clark, R. (1997). The puzzle of whole-school change. Phi Delta Kappan, 78, 690-697.

Wellisch, J. B., MacQueen, A. H., Carriere, R. A., \& Duck, G. A. (1978). School management and organization in successful schools. Sociology of Education, 51, 211-221.

Whitaker, K. S. (1998). The changing role of the principal: View from the inside. Planning and Changing, 29, 130-150.

Whitaker, S. D. (2000). Mentoring beginning special education teachers and the relationship to attrition. Exceptional Students, 66, 546-566. 


\section{SPECIAL EDUCATION POLICY AND PRACTICE}

\section{Accountability, Instruction, and Social Challenges}

Thomas M. Skrtic

Karen R. Harris

James G. Shriner

This is an excellent book that addresses the policy shift in special education from procedural compliance to standards-based accountability and the changing conditions of practice under reform. It covers the major problems of implementing reform and presents several practices and models to improve the conditions of special education practice.

The authors support a collaborative environment for service delivery and inclusive work atmospheres with research-based instructional practices. The book gives prevention and intervention strategies including specific reading, writing, and mathematics instructional techniques. Other topics include transition, selfdetermination, school violence, health needs, and literacy instruction for Latino students.

The focus in the last part of the book is oriented to human needs and opportunities that will shape special education practice in the future including individual and environmental conditions. These include welfare of children working across social contexts and providing a planning framework for achieving integrated services.

\section{SPECIAL FEATURES}

- Clear explanation of policy shifts from procedural compliance with federal and state law to academic performance of students with disabilities

- Recommends strategies for improving academic learning for students with disabilities

- Considers human needs and environmental conditions that contribute to educational achievement of children

- Provides an action-oriented planning framework for achieving integrated services 


\section{Professional update}

\section{TASH Conference}

November 17-20, 2004

Reno, Nevada

Contact: 410-828-8274

Web site: www.tash.org

American Speech-Language-Hearing Association Conference

November 18-20, 2004

Philadelphia, Pennsylvania

Contact: 301-897-5700

Web site: www.asha.org
Learning Disabilities Association International Conference

March 2-5, 2005

Reno, Nevada

Contact: 412-341-1515

Web site: www.ldanatl.org

National Association of School Psychologists Annual Conference

March 29-April 2, 2005

Atlanta, Georgia

Contact: 301-657-0270

Web site: www.nasponline.org 